\title{
Tree Species Effects on Soil Properties and Greenhouse Gas Fluxes in East-central Amazonia: Comparison between Monoculture and Diverse Forest
}

\author{
Joost van Haren ${ }^{1,7}$, Raimundo Cosme de Oliveira $\mathrm{Jr}^{2}$, Patrick Troy Beldini ${ }^{3}$, Plinio Barbosa de Camargo ${ }^{4}$, Michael Keller ${ }^{5}$, and Scott $^{2}$ \\ Saleska ${ }^{6}$ \\ ${ }^{1}$ Biosphere 2, University of Arizona, PO Box, Tucson, AZ, 85738, U.S.A. \\ ${ }^{2}$ EMBRAPA Amazônia Oriental, Santarém, Pará, Brazil \\ ${ }^{3}$ Universidade Federal do Oeste do Pará, Santarém, Pará, Brazil \\ ${ }^{4}$ CENA, Piracicaba, Sao Paulo, Brazil \\ ${ }^{5}$ University of New Hampshire, Durham, NH, U.S.A. \\ ${ }^{6}$ Department Ecology and Evolutionary Biology, University of Arizona, Tucson, AZ, U.S.A.
}

\section{ABSTRACT}

Tropical plantations are considered a viable option to sequester carbon on abandoned agricultural lands, but implications of tree species selection for overall greenhouse gas budgets on plantations have been little studied. During three wet seasons, we investigated the influence of nine tree species on soil $\mathrm{pH}$, temperature (ST), bulk density (BD), moisture content water filled pore space (WFPS), and greenhouse gas fluxes in diverse forest sites and monoculture plantation plots. All sites were on clay-rich soils of the Barreiras formation, in east-central Amazonia, Brazil. We found that ST and BD were $0.6^{\circ} \mathrm{C}$ and $0.2 \mathrm{~g} / \mathrm{cm}^{3}$ higher in the plantation relative to the forest, and soil $\mathrm{CH}_{4}, \mathrm{CO}, 2$ and $\mathrm{N}_{2} \mathrm{O}$ fluxes were, respectively, 38, 12, 62, percent lower in the plantation. Tree growth rates were highly variable on the plantation, with the mean comparable to the forest sites. Tree species identity mattered $(P<0.01)$ for all soil properties and gas fluxes on the plantation, but only for $\mathrm{pH}, \mathrm{BD}$, WFPS, and $\mathrm{N}_{2} \mathrm{O}$ fluxes in the forest. The species rank order of $\mathrm{pH}$ and $\mathrm{N}_{2} \mathrm{O}$ fluxes in the forest, however, were unlike the plantation. Tree growth rates were a strong predictor for soil WFPS, and together with location, they also explained 75 percent of the mean $\mathrm{N}_{2} \mathrm{O}$ flux variation. Our study indicates that: (1) tree species influence soil processes; and (2) high tree growth and low soil gas emissions imply a reduced climate forcing effect from plantations, especially when planted with fast-growing legume species on abandoned farmland.

Abstract in Portuguese is available in the online version of this article

Key words: carbon dioxide; methane; nitrous oxide; plantation; tree growth; tropical.

Tree Plantations CAN INCREASE CARBOn SEQUeStration ON ABANDONED AGricultural and pasture lands in the tropics (Montagnini \& Nair 2004). Besides carbon sequestration, tropical tree plantations can provide multiple services, such as pulpwood, hardwood, fruits, and medicinal oils (Silver et al. 2000). Plantations currently cover more than 60 million ha globally and are expanding rapidly in southeast Asia and south America (FAO 2010), though their expansion potentially will conflict with the need for food security in the tropics (DeFries \& Rosenzweig 2010). Few studies have investigated the methane $\left(\mathrm{CH}_{4}\right)$ and nitrous oxide $\left(\mathrm{N}_{2} \mathrm{O}\right)$ soil gas fluxes of plantation forests (Palm et al. 2002, Akimoto et al. 2005, Ishizuka et al. 2005, Arai et al. 2008). Relatively small trace gas fluxes can have a large impact, since $\mathrm{CH}_{4}$ and $\mathrm{N}_{2} \mathrm{O}$ have global warming potentials 23 and 296 times that of $\mathrm{CO}_{2}$ (IPCC 2007) and $\mathrm{N}_{2} \mathrm{O}$ has become the main cause for ozone destruction in the stratosphere (Ravishankara et al. 2009).

We expect soil gas fluxes to vary with species, because plantation studies have found that plant species can influence

Received 29 January 2013; revision accepted 18 May 2013.

${ }^{7}$ Corresponding author; e-mail: jvanhare@email.arizona.edu soil properties and processes (Montagnini \& Sancho 1990, Valverde-Barrantes 2007, Brechet et al. 2009). Tree species influence on soil properties has remained difficult to quantify in diverse forests (e.g., Powers et al. 2004), though recent studies have been able to demonstrate species effects on soil properties in diverse tropical forests (van Haren et al. 2010). Other researchers have argued that to avoid inherent soil variability we have to use monoculture plantations (common gardens) to determine tree species effects on soil nutrient and greenhouse gas production (Binkley \& Menyailo 2005, Brechet et al. 2009). Though, Binkley and Menyailo (2005) also warn for the potential pitfalls of monocultures by arguing that they are not a realistic rendering of nature and that the trees are consistently young. Mixed species experiments of litter decomposition (Hattenschwiler et al. 2005), nutrient cycling (Jacob et al. 2009), and above ground biomass growth (Piotto 2008) have found that species effects are not additive and that species-specific effects disappear in mixed cultures (Murphy et al. 2008). This raises the question: how realistic are monoculture derived plant species effects on soil properties and greenhouse gas production with respect to diverse forest settings? 
In an earlier paper we have shown that tree species identity matters for soil $\mathrm{N}_{2} \mathrm{O}$ fluxes in diverse forests (van Haren et al. 2010). In this article, we compare nine tree species both measured on a monoculture plantation and in diverse forests with regard to associated soil physical characteristics and greenhouse gas fluxes. The goals were to: (1) estimate the overall greenhouse gas impact of monoculture plots on a plantation versus natural forest sites; (2) determine tree species influence on soil properties and gas fluxes in a native species, monoculture plantation; and (3) determine whether plantations carry predictive capability for tree species influence in a diverse forest. Since our monoculture was planted on abandoned agriculture land, we expected in comparison with the forest sites the overall gas fluxes to be lower, due to resource depletion of the plantation soil; soil temperature (ST) to be higher and water filled pore space (WFPS) to be lower, due to increased openness of the canopy; and the bulk density (SD) to be higher, due to reduced organic matter content and soil compaction due to mechanized agriculture practices. Based on the finding that species effects disappear in mixed culture (Murphy et al. 2008) we hypothesized that species differences would be more pronounced in monoculture than in the diverse forest. Furthermore, we hypothesized that $\mathrm{N}_{2} \mathrm{O}$ fluxes would be higher on legume tree species plots, since legume species can have lower soil nitrogen demand due to root associated $\mathrm{N}$-fixation. Lastly, based on our previous finding that soil $\mathrm{N}_{2} \mathrm{O}$ fluxes were negatively related to tree growth rates (van Haren et al. 2010), we predicted that soil gas fluxes in the plantation were lower on plots of faster growing tree species.

\section{METHODS}

Site Description and SPeCies Selection.-We measured soil gas fluxes in three clay-rich, primary forest sites and in one plantation site just north of the Tapajós National Forest (TNF) south of Santarém, Pará, Brazil (see Fig. S1 and Table 1). Mean annual temperature in the region is $25.0^{\circ} \mathrm{C}$ and annual precipitation average is $1920 \mathrm{~mm}$ with a pronounced dry season from July through December (Parotta et al. 1995). In the forest, vegetation dynamics transects were established in 1999 (Rice et al. 2004) and 2001 (Pyle et al. 2008). The forest vegetation is diverse with 114 species in $20 \mathrm{ha}$ (diameter at breast height [dbh] $>35 \mathrm{~cm}$ ). Soils at the forest and plantation sites are texturally homogeneous and consist of clay-rich Oxisol (clay content $>85 \%$, Table 1). Most common emergent and upper canopy tree species are Carapa guianensis, Chamaecrista xinguensis, Couratari stellata, Erisma uncinatum, Lecythis lurida, Manilkara buberi, and Sclerolobium chrysopbyllum, though their local abundance varies within the forest (Parotta et al. 1995). For our study we selected 15 upper canopy and emergent species in the forest and ten species on the plantation (Table 2), with legumes and shade-tolerant functional groups both represented. Nine of the tree species were present both in the forest and plantation, these species were used for the comparison between the two land-use types.

The Empresa Brasileira de Pesquisa Agropecuaria (EMBRAPA) species test plantation in Belterra (Fig. S1) was established in
1978 on abandoned pasture farmland, which previously had been a rubber plantation (Russell 1942). Species were planted in monoculture in variable size plots $(0.01-0.5 \mathrm{ha})$ on clay-rich soil (Table 1). After establishment, the EMBRAPA plantation has been maintained throughout and kept relatively free of understory trees. Canopy development was dependent on the tree sun tolerance and ability to do well in plantation settings. Shade intolerant tree species, such as Betholletia excelsa, C. guianensis, Copaifera multijuga, and L. lurida plots, contain developed trees with dense canopies and therefore a clean understory. In contrast, shade tolerant species like Astronium lecontei and M. buberi trees have remained relatively small and the plots are very open and thus allowed for more in-growth. Understory plants and branch litter were removed from all plots one to 2 days prior to the flux measurements. Replicate plots only existed on the plantation for B. excelsa and Vochysia maxima, for which we measured three and two separate plots respectively.

FLUX AND SUPPORTING MEASUREMENTS.-All measurements have been described in detail in van Haren et al. (2010). We measured air temperature (AT) and ST with handheld temperature probes (accurate at $\left.\pm 0.2^{\circ} \mathrm{C}\right)$ and collected soil samples $(0-3 \mathrm{~cm}$ depth) for $\mathrm{BD}$ and soil moisture (SM) analyses in aluminum soil rings (diameter $=5 \mathrm{~cm}$ ), which were weighed on the collection day and dried at $105^{\circ} \mathrm{C}$ for at least $24 \mathrm{~h}$. We calculated percent WFPS from BD and SM according to Linn and Doran (1984). In-situ soil $\mathrm{pH}$ was measured with a rugged gel-filled electrode (Omega PHE-2385, Omega Engineering, Stamford, Connecticut, U.S.A.) and Omega PHH222 $\mathrm{pH} / \mathrm{mV}$ meter $(<5 \mathrm{~cm}$ depth and at four replicates per flux location). Every eight samples, the electrode

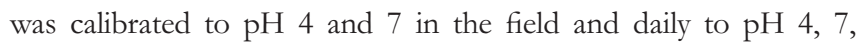
and 10 in the lab.

In the forest, we measured soil gas fluxes within $0.5-3 \mathrm{~m}$ from the stems of large $(\mathrm{dbh}>35 \mathrm{~cm})$ randomly selected stems of each species (van Haren et al. 2010). The sampling location relative to the tree (distance and direction) was selected with a random number generator; we also had an alternate location if a tree was blocking the first location choice. At each plot on the plantation, we placed chambers for flux measurements $>5 \mathrm{~m}$ from the edge of the plot, at random distances from the trees. We decided on two different sampling strategies, because of: (1) potential species interference in the forest, flux measurements were required to be taken close to the focal tree stem, and (2) trees were planted at $\sim 3-6 \mathrm{~m}$ distance within most plots in the plantation, thus most flux locations would be within the $3 \mathrm{~m}$ radius from a tree stem. All 348 flux (186 and 162 fluxes in the forest $[\mathrm{F}]$ and plantation $[\mathrm{P}]$, respectively) measurements were conducted during 24 days in the late wet season, April, May, and early June of 2006 (six F and three P days), 2007 (nine F and four P), and 2009 (two P). We measured greenhouse gas fluxes only in the wet season since many studies have found that dry season fluxes, and thus potential species differences, are greatly reduced compared with wet season fluxes (Breuer et al. 2000, Keller et al. 2005, Werner et al. 2007, Murphy et al. 2008, Brechet et al. 2009). 
TABLE 1. Mean soil properties and gas fluxes ( \pm SE) for all sampling locations in the forest and plantation (letters denote significant difference $\mathrm{P}<0.05$, within columns). ST, soil temperature; BD, bulk density; WFPS, water filled pore space.

\begin{tabular}{|c|c|c|c|c|c|c|c|c|}
\hline & $\%$ Sand & $\mathrm{pH}$ & ST $\left({ }^{\circ} \mathrm{C}\right)$ & $\mathrm{BD}\left(\mathrm{g} / \mathrm{cm}^{3}\right)$ & WFPS & $\mathrm{CO}_{2} \mathrm{mg}-\mathrm{C} / \mathrm{m}^{2} / \mathrm{h}$ & $\mathrm{N}_{2} \mathrm{O} \mu \mathrm{g}-\mathrm{N} / \mathrm{m}^{2} / \mathrm{h}$ & $\mathrm{CH}_{4} \mu \mathrm{g}-\mathrm{C} / \mathrm{m}^{2} / \mathrm{h}$ \\
\hline \multicolumn{9}{|l|}{ Plantation $(n)$} \\
\hline Belterra (174) & $3.6 \pm 0.4^{\mathrm{b}}$ & $3.55 \pm 0.02^{\mathrm{ab}}$ & $25.7 \pm 0.05^{\mathrm{a}}$ & $0.91 \pm 0.01^{\mathrm{a}}$ & $60.7 \pm 1.4^{\mathrm{b}}$ & $228 \pm 6^{\mathrm{b}}$ & $26 \pm 2^{c}$ & $-17.0 \pm 4.0^{\mathrm{a}}$ \\
\hline $2007(70)$ & & $3.59 \pm 0.02^{\mathrm{a}}$ & $25.9 \pm 0.05^{\mathrm{a}}$ & $0.87 \pm 0.01^{\mathrm{b}}$ & $72.1 \pm 1.2^{\mathrm{b}}$ & $242 \pm 14$ & $30 \pm 3^{a}$ & NA \\
\hline $2009(40)$ & & $3.44 \pm 0.06^{\mathrm{b}}$ & $24.7 \pm 0.1^{\mathrm{b}}$ & NA & NA & $237 \pm 13$ & $16 \pm 4^{\mathrm{b}}$ & NA \\
\hline km72 (80) & $1.2 \pm 0.4^{\mathrm{b}}$ & $3.45 \pm 0.03^{\mathrm{b}}$ & $25.2 \pm 0.05^{\mathrm{bc}}$ & $0.70 \pm 0.02^{\mathrm{c}}$ & $55.9 \pm 1.3^{\mathrm{c}}$ & $260 \pm 10^{\mathrm{a}}$ & $46 \pm 4^{\mathrm{b}}$ & NA \\
\hline km83 (72) & $17.5 \pm 2.6^{\mathrm{a}}$ & $3.59 \pm 0.03^{\mathrm{a}}$ & $25.4 \pm 0.09^{\mathrm{b}}$ & $0.80 \pm 0.02^{\mathrm{b}}$ & $66.9 \pm 1.1^{\mathrm{a}}$ & $260 \pm 15^{\mathrm{ab}}$ & $111 \pm 9^{\mathrm{a}}$ & NA \\
\hline $2006(129)$ & & NA & $24.7 \pm 0.03^{\mathrm{b}}$ & $0.72 \pm 0.01$ & $52.5 \pm 0.9^{\mathrm{b}}$ & $262 \pm 9$ & $82 \pm 5$ & $-44 \pm 7^{b}$ \\
\hline 2007 (211) & & $3.55 \pm 0.02$ & $25.5 \pm 0.05^{\mathrm{a}}$ & $0.75 \pm 0.01$ & $62.8 \pm 1.2^{\mathrm{a}}$ & $255 \pm 7$ & $74 \pm 4$ & NA \\
\hline \multicolumn{9}{|c|}{ Forest-Plantation comparison using Welch ANOVA equal means test } \\
\hline
\end{tabular}

*This article focuses on the comparison between species both present in the forest and plantation; however, soil properties and gas fluxes were measured close to 16 and 10 tree species in the forest and plantation respectively.

TABLE 2. Tree species used for greenhouse gas flux measurements in monoculture and forest sites in east-central Amaronia.

\begin{tabular}{|c|c|c|c|c|c|c|c|}
\hline Anacardiaceae & Astronium & lecointei & Ducke & Aroeira & $\mathrm{AL}$ & Tolerant & No \\
\hline Caryocaraceae & Caryocar & villosum & (Aubl.) Pers & Piquia & $\mathrm{CV}$ & Not & No \\
\hline Fabaceae (Caes.) & Sclerolobium & chrysophyllum & Poepp. & Tachi vermelho & SC & Not & Yes \\
\hline Lecythidaceae & Bertholletia & excelsa & Humb.\&Bonpl. & Castanha do Pará & $\mathrm{BE}$ & Not & No \\
\hline Sapotaceae & Manilkara & buberi & (Ducke) Chev. & Maçaranduba & MH & Tolerant & No \\
\hline Vochysiaceae & Vochysia & maxima & Ducke & Quaruba verdadeira & VM & Not & No \\
\hline
\end{tabular}

Tree species were initially identified in 1999 along the km 67 transects by Nelson A. Rosa from the Museu Emilio Goeldi in Belém, Pará, where voucher specimens are stored in the museum collection. During our field campaigns, Nilson de Souza Carvalho (EMBRAPA, Belterra, Pará) conducted all the tree identifications. All tree species are also described in Parotta et al. 1995.

Since we could not sample all species evenly each day, we randomly selected species for flux measurements in the forest and plantation. For each flux measurement, we installed chamber bases $\sim 2 \mathrm{~cm}$ into the soil and within one hour -to minimize root decomposition effects (Matson et al. 1990)- drew at $10 \mathrm{~min}$ intervals four $20 \mathrm{ml} \mathrm{B \& D}{ }^{\circledR}$ plastic syringes (Becton, Dickinson and Company, Franklin Lanes, New Jersey, U.S.A.). Within 36 h, we analyzed all syringes for $\mathrm{CH}_{4}, \mathrm{CO}_{2}$, and $\mathrm{N}_{2} \mathrm{O}$ on two Shimadzu gas chromatographs (GC) both with a $2 \mathrm{ml}$ injection loop and Porapak Q column $\left(1 / 8^{\prime \prime} \times 4^{\prime}\right.$ and column $\mathrm{T}$ at $\left.60^{\circ} \mathrm{C}\right)$. One GC was equipped with an FID detector for $\mathrm{CH}_{4}$ analysis using $\mathrm{N}_{2}$ as the carrier gas, the other with ECD detector at $300^{\circ} \mathrm{C}$ and P5carrier gas $\left(5 \% \mathrm{CH}_{4}\right.$ in $\left.\mathrm{Ar}\right)$. Gas fluxes were determined using linear regression of the four measurements and converted to weight per area per time with the AT and chamber volume.
We measured the diameter at breast height $(1.3 \mathrm{~m}$, dbh) of all trees within each plantation plot and within a $3 \mathrm{~m}$ radius of the flux location in the forest sites. Aboveground biomass was calculated from the dbh measurements and wood density values using the wet tropical forest equation from Chave et al. (2005):

$$
\begin{aligned}
\text { Bomass }= & \text { density } * \exp (-1.499+2.148 * \ln (d b h)+0.207 \\
& \left.*[\ln (d b h)]^{2}-0.0281 *[\ln (d b b)]^{3}\right)
\end{aligned}
$$

Tree growth rates in the forest were taken from annual dbh measurements on all trees $>35 \mathrm{~cm}$ dbh conducted since 2005, and in the plantation were obtained from repeated dbh measurements in 2006, 2007, and 2009. Growth rates (kg/yr) were calculated by subtracting the mass calculated with the allometric equation of the earlier year from the later year tree mass. 
In 2009, we collected old and new leaves from all tree species on the plantation. The samples were dried and ground after which they were transported to the stable isotope laboratory at CENA, Piracicaba, Brazil for $\mathrm{C}$ and $\mathrm{N}$ concentration and their isotope composition, using a Carlo Erba Elemental analyzer (Carlo Erba, Milan, Italy) connected to a Finnigan Mat Delta Plus (Thermo Fisher Scientific Inc., Waltham, Massachusetts, U.S.A.). The resulting data were compared with the concentration and isotope composition of leaves from the same species collected in the Tapajos National Forest.

Statistical anALYSES.-To determine whether individual samples were independent and thus could be treated as replicates within the plot scale, we used the geoR package in R (Ribeiro \& Diggle 2001) to construct semi-variograms for each of the soil parameters and gas fluxes. Since most sampling locations were visited only once a year, all samples were pooled for the different dates across each year for statistical analyses. Measured parameters were tested for normality and log-transformed when appropriate and back-transformed before reporting. We used Student's $t$-test to compare the measured soil parameters and gas fluxes between the forest and plantation, and ANOVA with sites, species, and year as independent variables, followed by the Tukey-Kramer Honestly Significant Difference procedure to compare all measured parameters. We conducted multiple linear regression using the standard least squares method to determine the mixed effects of the independent variables species, site, and species $\times$ site on the dependent variables pH, ST, BD, WFPS, and $\mathrm{CH}_{4}, \mathrm{CO}_{2}$, and $\mathrm{N}_{2} \mathrm{O}$ fluxes. We used the Akaike information criterion (AICc) to compare the different models fit. Except for the spatial statistics, all statistical analysis were done using in JMP (v. 10.0.0; SAS Institute, Cary, North Carolina, U.S.A.).

\section{RESULTS}

Semi-variogram analysis within the forest and plantation suggested that all parameters (except for BD and WFPS) were independent within each plot $(<1 \mathrm{~m})$ and that for all the flux measurements the individual data points could be regarded as replicates (Figs. S2 and S3). Only ST (data not shown), BD, and WFPS in the plantation showed a small range, indicative of spatial dependence at scales from 10 to $30 \mathrm{~m}$. The nugget effect was very large for all variables, which suggests that most variance occurs within very small distances (Fig. S3).

Plantation versus forest.-On average soil $\mathrm{CH}_{4}, \mathrm{CO}_{2}$, and $\mathrm{N}_{2} \mathrm{O}$ fluxes were respectively 38,12 , and 66 percent lower on the plantation relative to the clay-rich forest sites (Table 1 and Fig. 1). ST and $\mathrm{BD}$ on the plantation were, respectively, $0.6^{\circ} \mathrm{C}$ and $0.17 \mathrm{~g} / \mathrm{cm}^{3}$ higher than the forest sites. Soil $\mathrm{pH}$ and WFPS were indistinguishable on plantation and forest sites. Aboveground biomass was highly variable on the plantation, ranging from $\sim 50$ to $300 \mathrm{MgC} / \mathrm{ha}$ ). On average, the plantation biomass was comparable to that of the forest sites $(175 \pm 27$ vs. $200 \pm 10 \mathrm{MgC} / \mathrm{ha}$, Table 3). On the plantation, annual tree growth ranged from 1.5

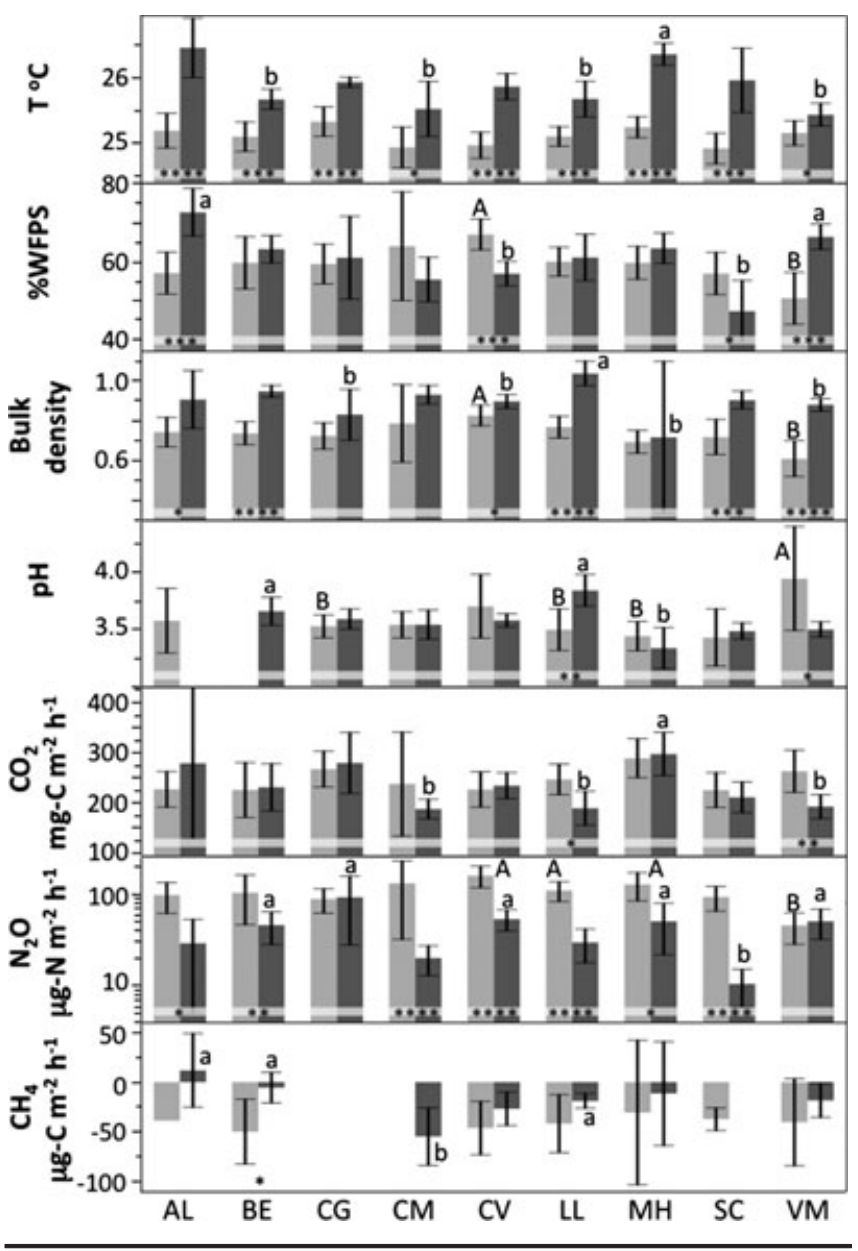

FIGURE 1. Bar plots by species of all measured soil variables both in the forest (light grey filled bars) and plantation (dark grey bars). Error bars indicate the $95 \%$ CI for each species and location. Stars in the white transparent bar indicate significant differences between forest and plantation ( $t$-test: $*=0.05, * *=0.01, * * *=0.001$, and $* * * *=0.0001)$. The letters above the bars indicate species differences $(\alpha=0.01)$; lower case letters denote species differences within the plantation, upper case in the forest.

to $10.1 \mathrm{MgC} / \mathrm{ha} / \mathrm{yr}$, though the geometric mean was indistinguishable from the forest $(4.5 \pm 0.8$ vs. $\sim 3.9 \mathrm{MgC} / \mathrm{ha} / \mathrm{yr})$.

TREe SPECIES DIFFERENCES.-For the few replicated plots we sampled, we found that aboveground biomass, soil properties, and gas fluxes were nearly identical on separate plots of $B$. excelsa and $V$. maxima, only ST was respectively 1.0 and $0.9^{\circ} \mathrm{C}$ lower on one of the plots. Tree species explained more (two to three times) variance of ST, pH, BD, WFPS, $\mathrm{CH}_{4}, \mathrm{CO}_{2}$, and $\mathrm{N}_{2} \mathrm{O}$ fluxes on the plantation than at forest sites (Table 3 and Fig. 1), with soil pH and $\mathrm{N}_{2} \mathrm{O}$ fluxes best ( 30 and $16 \%$ in the plantation and forest, respectively) and $\mathrm{CO}_{2}$ and $\mathrm{CH}_{4}$ fluxes least well (0.13 and 0.07 respectively) explained by species. For all soil parameters species differences were significant $(P<0.05)$ on the plantation, but not for ST, $\mathrm{CH}_{4}$, and $\mathrm{CO}_{2}$ fluxes in the forest. Soil $\mathrm{CH}_{4}$ fluxes close to the different species were statistically indistinguishable within 


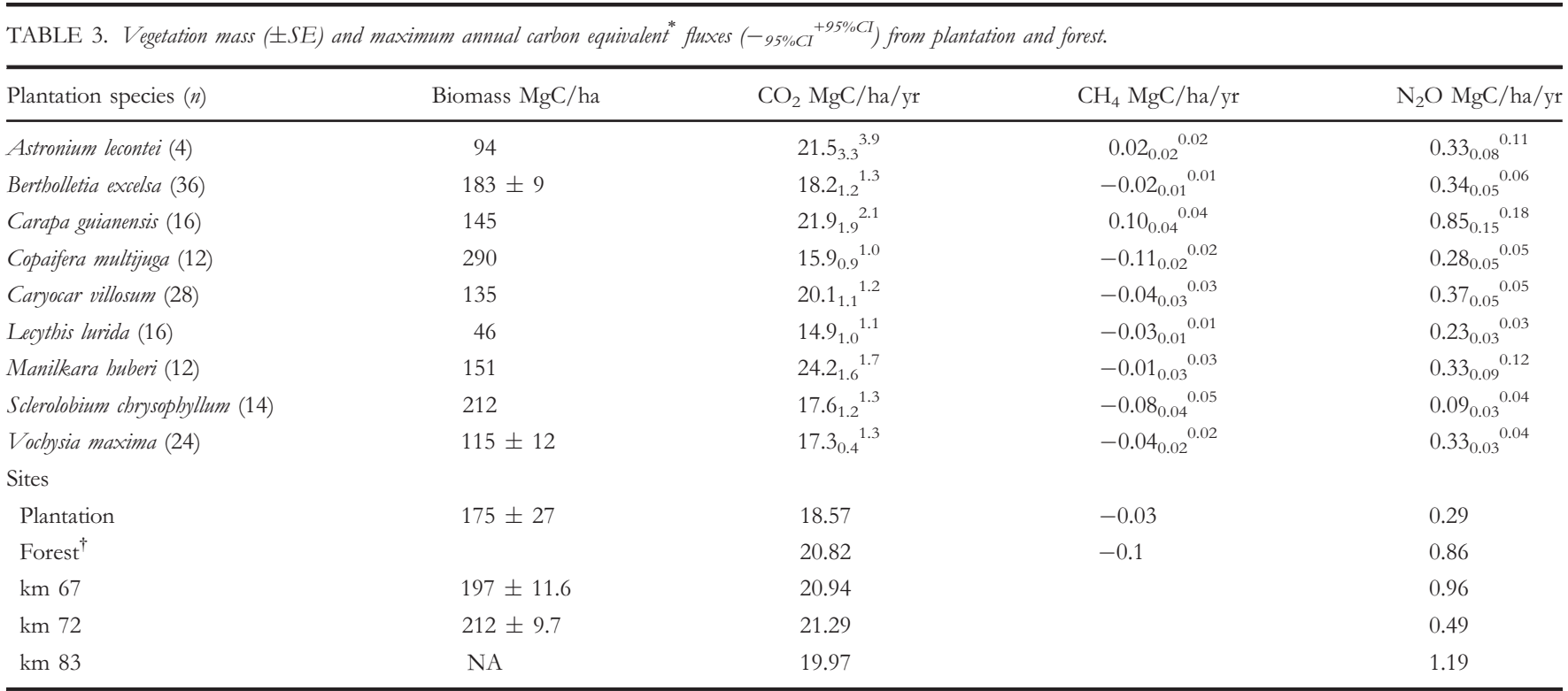

*Carbon equivalent fluxes were calculated based on the wet season fluxes only, and therefore represent a maximum estimate, and the difference in global warming potential (IPCC 2007) of the gases $\left(1,23,296\right.$, for $\mathrm{CO}_{2}, \mathrm{CH}_{4}$, and $\mathrm{N}_{2} \mathrm{O}$, respectively).

$\dagger$ Forest biomass values were obtained from Pyle et al. (2008).

TABLE 4. Rank order (bighest to lowest) of species for the growth rate, soil pH, and $\mathrm{N}_{2} \mathrm{O}$ flux.

\begin{tabular}{|c|c|c|c|c|c|c|}
\hline \multirow[b]{2}{*}{ Rank } & \multicolumn{2}{|c|}{ Tree growth } & \multicolumn{2}{|c|}{$\mathrm{pH}^{*}$} & \multicolumn{2}{|c|}{ Soil $\mathrm{N}_{2} \mathrm{O}$ flux } \\
\hline & Forest & Plantation & Forest & Plantation & Forest & Plantation \\
\hline 1 & $\mathbf{V M}^{\dagger}$ & CM & VM & LL & $\mathrm{CV}$ & CG \\
\hline 2 & $\mathrm{SC}$ & SC & $\mathrm{CV}$ & $\mathrm{CV}$ & $\mathbf{C M}$ & $\mathrm{CV}$ \\
\hline 3 & $\mathrm{BE}$ & $\mathrm{BE}$ & $\mathrm{AL}$ & $\mathrm{BE}$ & $\mathbf{L L}$ & $\mathrm{BE}$ \\
\hline 4 & $\mathrm{AL}$ & $\mathrm{MH}$ & CG & CG & $\mathrm{MH}$ & VM \\
\hline 5 & $\mathrm{MH}$ & CG & $\mathbf{L L}$ & $\mathrm{CM}$ & $\mathrm{BE}$ & $\mathrm{AL}$ \\
\hline 6 & CM & $\mathrm{CV}$ & $\mathrm{CM}$ & VM & $\mathrm{AL}$ & MH \\
\hline 7 & CG & VM & $\mathrm{MH}$ & $\mathrm{MH}$ & CG & $\mathbf{C M}$ \\
\hline 8 & $\mathrm{CV}$ & $\mathrm{AL}$ & SC & SC & SC & $\mathbf{L L}$ \\
\hline 9 & LL & LL & & & VM & SC \\
\hline
\end{tabular}

${ }^{*} \mathrm{pH}$ was not measured on the Betholletia excelsa plots in the plantation and close to Astronium lecontei in the forest.

$\dagger$ Species abbreviations in bold signifies a difference of $>4$ ranks between plantation and forest.

the forest, but on the plantation $\mathrm{CH}_{4}$ fluxes on $A$. lecontei, B. excelsa, and L. lurida plots were 119, 85, and 65 percent greater than on the C. multijuga monoculture (Fig. 1). We found that on the plantation mean soil $\mathrm{CO}_{2}$ flux measured within C. guianensis plots was 75,128 , and 78 percent greater than in C. multijuga, $L$. lurida, and $V$. maxima plots respectively (Table 3 and Fig. 1). Extraordinarily high $\mathrm{CO}_{2}$ fluxes $335 \pm 30 \mathrm{mg}-\mathrm{C} / \mathrm{m}^{2} / \mathrm{h}$ on the C. guianensis and $M$. huberi plots were the result of a very thick $(2-5 \mathrm{~cm})$ litter layer. When we removed the litter layer, the $\mathrm{CO}_{2}$ flux was reduced by $\sim 31$ percent to $231 \pm 18 \quad(P<0.01$, $N=24$ ), but the $\mathrm{N}_{2} \mathrm{O}$ flux did not decrease significantly (from
$51 \pm 11$ to $\left.45 \pm 11 \mu \mathrm{g}-\mathrm{N} / \mathrm{m}^{2} / \mathrm{h}, P<0.35, N=24\right)$. For all samples, a model with ST and BD predicted 17 percent of $\mathrm{CO}_{2}$ flux variability, whereas species means of ST and BD predicted 56 percent of species mean $\mathrm{CO}_{2}$ flux variability $(P<0.0001)$ :

$\mathrm{CO}_{2}=38 * \mathrm{ST}-294 * \mathrm{BD}-474$.

On the plantation, mean soil $\mathrm{N}_{2} \mathrm{O}$ fluxes were 78 and 76 percent smaller within $S$. chrysophyllum plots than in Caryocar villosum and $V$. maxima plots. In the forest, we did not observe any species differences except for tree growth rates, soil $\mathrm{pH}$ (higher close to $V$. maxima than $M$. huberi and S. chrysophyllum), and $\mathrm{N}_{2} \mathrm{O}$ flux (C. villosum and L. lurida higher than $V$. maxima).

The relative ranking of species geometric means for tree growth rate, soil $\mathrm{pH}$, and $\mathrm{N}_{2} \mathrm{O}$ fluxes (the only variables with species level differences in both the forest and plantation; Table 3 and Fig. 1) in forest and plantation was most different for $\mathrm{N}_{2} \mathrm{O}$ fluxes (Table 4). Four of nine species shifted at least five positions (more than half the ranking) for $\mathrm{N}_{2} \mathrm{O}$. Only two species made a comparable shift for tree growth rate and soil $\mathrm{pH}$.

Tree growth rate could explain 30 percent of tree species mean soil WFPS, which decreased with increasing tree growth rate. We compared the potential of leaf chemistry, tree growth rate, and soil properties on species mean soil gas fluxes. Of the tree species-specific explanatory variables, tree growth rate, together with location identity, could explain 66 percent of species mean $\mathrm{N}_{2} \mathrm{O}$ flux variability (Fig. $2 \mathrm{~A}, P<0.0001$ ):

$\mathrm{N}_{2} \mathrm{O}=-0.7 *$ TreeGrowth $+\left\{\begin{array}{c}\text { forest }: 30 \\ \text { plantation }:-30\end{array}+68\right.$

However, a model of WFPS, location identity, and WFPSxlocation best explained species mean soil $\mathrm{N}_{2} \mathrm{O}$ fluxes $(90 \%$; 

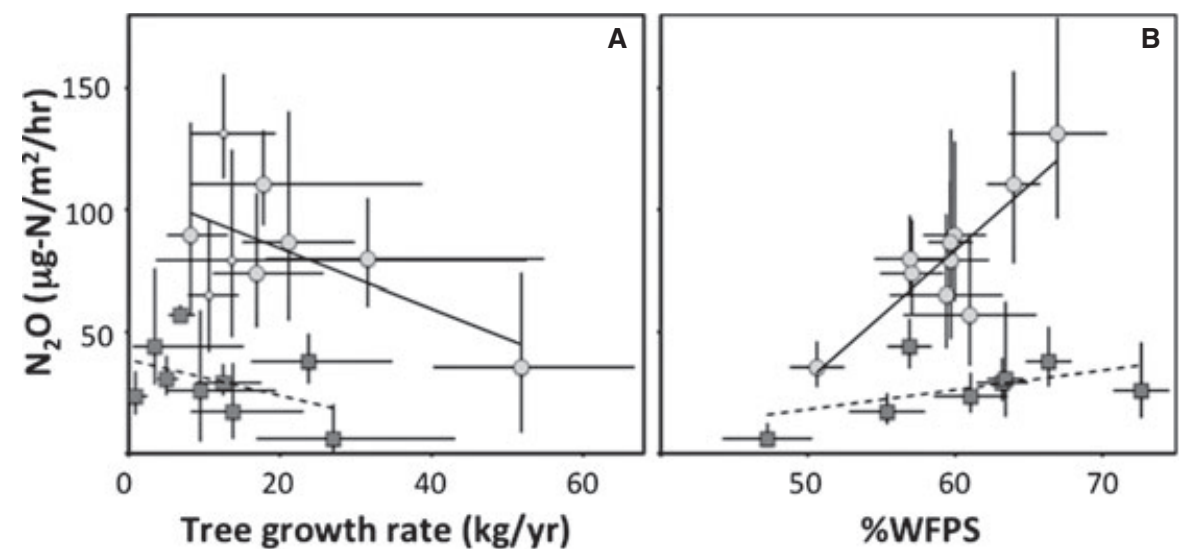

FIGURE 2. Multiple linear regression plots of tree species mean soil $\mathrm{N}_{2} \mathrm{O}$ flux versus (A) tree growth rate + site (forest vs. plantation) and (B) $\%$ water filled pore space (WFPS) + site +\%WFPS* site. The model with\% (WFPS) (B) had the lower AICc (213 vs. 227) and was deemed the better model to predict soil $\mathrm{N}_{2} \mathrm{O}$ fluxes.

AICc $=213$ vs. 227 for the growth rate and location model, Fig $2 \mathrm{~B}, P<0.0001)$ :

$$
\begin{aligned}
\mathrm{N}_{2} \mathrm{O}= & 3.4 * \text { WFPS }+\left\{\begin{array}{c}
\text { forest }: 29 \\
\text { plantation }:-29
\end{array}+(\text { WFPS }-60)\right. \\
& *\left\{\begin{array}{c}
\text { forest }: 2.4 \\
\text { plantation }:-2.4
\end{array}-135\right.
\end{aligned}
$$

Comparison of samples collected on legume versus nonlegume species plots on the plantation indicates that on average legumes on the plantation had growth rates over twice those of non-legumes $(P<0.0001$, see Table 5). Soil $\mathrm{pH}$ values on legume plots were 0.1 lower $(P=0.006)$, WFPS 10 percent lower $(P<0.001)$, and $\mathrm{N}_{2} \mathrm{O}$ fluxes 60 percent lower $(P<0.0001)$ than for non-legume plots on the plantation. In the forest, the soil $\mathrm{pH}$ values close to legume trees were 0.15 lower $(P=0.02)$ than close to non-legumes. Legume leaf $\delta^{15} \mathrm{~N}$ composition was identical to those of non-legumes (Table 6), both in the forest and on the plantation. Only the $\delta^{13} \mathrm{C}$ and $\mathrm{C}$-content of the leaves were respectively 6 percent lower and 7 percent higher in legumes relative to non-legumes on the plantation.

\section{DISCUSSION}

FOREST VERSUS PLANTATION.-Plantations replacing abandoned agricultural lands represent a viable option to offset some human carbon emissions or reduce emissions from deforestation and forest degradation (Silver et al. 2000, Montagnini \& Nair 2004, Russell et al. 2010). In our study, the aboveground tree biomass on the plantation was comparable to the forest, though the variability on the plantation was very large (Table 3). This suggests that fast growing tree species in monoculture can achieve the biomass density of primary forests in $\sim 25$ years.

Soil gas fluxes measured in the forest sites were similar to fluxes measured previously during the wet season in the TNF (Keller et al. 2005, Davidson et al. 2008) and the plantation fluxes were similar to wet season fluxes reported from sandy forest sites in the TNF (Keller et al. 2005, Silver et al. 2005). Soil $\mathrm{CH}_{4}$ fluxes change with land-use change (Wick et al. 2005) and logging (Keller et al. 2005), mainly due to soil compaction by the use of machines. We therefore expected higher $\mathrm{CH}_{4}$ fluxes on the plantation. The difference between our plantation and forest measurements, however, was negligible compared with wet season $\mathrm{CH}_{4}$ fluxes from pastures and logging tracks and decks. Soil $\mathrm{CO}_{2}$ fluxes on the plantation were only 10 percent lower than forest fluxes and match wet season $\mathrm{CO}_{2}$ fluxes measured under degraded pasture in Rondonia (Cerri et al. 2006). This suggests that, in contrast with our prediction, soil $\mathrm{CO}_{2}$ fluxes are only marginally affected by land-use change, as long as vegetation is present. The species differences on the plantation are likely due to changes in litter density (M. buberi and $C$. guianensis having the highest $\mathrm{CO}_{2}$ fluxes and litter accumulation) and soil BD (L. lurida, where the highest soil $\mathrm{BD}$ and lowest $\mathrm{CO}_{2}$ flux). Across both forest and plantation $\mathrm{ST}$ and $\mathrm{BD}$ were the best predictors of soil $\mathrm{CO}_{2}$ fluxes, but not \%WFPS. Our result is in agreement with those from the drought experiment in the Tapajos forest, where a strong reduction in SM content did not reduce $\mathrm{CO}_{2}$ fluxes, presumable due to increased root activity (Davidson et al. 2008). Increased root density could also explain our observed negative correlation between $\mathrm{BD}$ and $\mathrm{CO}_{2}$ flux.

Plantation $\mathrm{N}_{2} \mathrm{O}$ fluxes were three to four times larger than those measured on agriculture sites with ages ranging from four to sixty years near the TNF (Wick et al. 2005). Soil $\mathrm{N}_{2} \mathrm{O}$ fluxes from the agricultural, plantation, and primary forest sites in and around the TNF follow a similar increasing trend with age compared with secondary forests in Paragominas, Brazil (Davidson et al. 2007). Leaf $\delta^{15} \mathrm{~N}$ values on the plantation were comparable to tree leaves in terra firme forests close to Manaus, Paragominas, and Sao Gabriel da Cachoeira (Davidson et al. 2007, Nardoto et al. 2008), but only half of those at clay-rich sites in the Tapajos National Forest. Likewise, soil nitrogen content was 0.25-0.29 
TABLE 5. Effects of legume tree species on soil parameters on the plantation and in the forest. ST, soil temperature; BD, bulk density; WFPS, water filled pore space.

\begin{tabular}{|c|c|c|c|c|c|c|c|c|}
\hline & Growth (kg-C/yr) & $\mathrm{pH}$ & ST $\left({ }^{\circ} \mathrm{C}\right)$ & $\mathrm{BD}\left(\mathrm{g} / \mathrm{cm}^{3}\right)$ & WFPS \% & $\mathrm{CO}_{2}\left(\mathrm{mg}-\mathrm{C} / \mathrm{m}^{2} / \mathrm{h}\right)$ & $\mathrm{N}_{2} \mathrm{O}\left(\mu \mathrm{g}-\mathrm{N} / \mathrm{m}^{2} / \mathrm{h}\right)$ & $\mathrm{CH}_{4} \quad\left(\mu \mathrm{g}-\mathrm{C} / \mathrm{m}^{2} / \mathrm{h}\right)$ \\
\hline \multicolumn{9}{|l|}{ Plantation } \\
\hline Non-legume (136) & $8 \pm 2$ & $3.57 \pm 0.03$ & $25.8 \pm 0.1$ & $0.91 \pm 0.01$ & $63 \pm 1$ & $233 \pm 9$ & $35_{3}{ }^{3}$ & $-14_{4}^{4}$ \\
\hline Student's $t$ & 3.0 & -2.9 & -2.0 & 0.9 & -5.0 & -1.8 & -7.0 & -1.9 \\
\hline Two-sided $P$ & 0.02 & 0.006 & 0.05 & 0.35 & $<0.0001$ & 0.07 & $<0.0001$ & 0.09 \\
\hline Legume (57) & $24 \pm 12$ & $3.42 \pm 0.05$ & $25.1 \pm 0.1$ & $0.76 \pm 0.02$ & $60 \pm 1$ & $253 \pm 13$ & $85_{7}^{8}$ & $-28_{14}{ }^{16}$ \\
\hline Student's $t$ & 0.0 & -2.4 & -1.3 & 1.6 & 0.7 & -1.1 & 1.1 & 0.0 \\
\hline Two-sided $P$ & 0.99 & 0.02 & 0.21 & 0.10 & 0.46 & 0.26 & 0.29 & 1.0 \\
\hline
\end{tabular}

percent (da Silva et al. 2000), which is comparable to Manaus Terra firme forest, but lower than clay soils of the TNF (0.3$0.5 \%$ N, Nardoto et al. 2008 and Williams et al. 2002). Our results suggest that plantation monocultures have a positive effect on soil nitrogen cycling similar to secondary forests, in agreement with a study on tree-based systems and secondary forests in Peru (Palm et al. 2002). Consequently, with increasing plantation age soil $\mathrm{N}_{2} \mathrm{O}$ fluxes are expected to increase and the net benefit with respect to greenhouse gas balance decreases. The scenario is consistent with the analysis of Silver et al. (2000) who found that medium age rotations (40-80 yr, when tree carbon and soil $\mathrm{CH}_{4}$ uptake is expected to be offset by soil $\mathrm{N}_{2} \mathrm{O}$ fluxes) are most beneficial to the overall carbon sequestration of plantation forests.

SPECIES IDENTITY AND GROWTH RATE EFFECTS.-The species differences we measured in monoculture plots on the plantation were detected on soil properties measured to $3 \mathrm{~cm}$ depth. This is where tree species have most influence on soil properties (Montagnini \& Sancho 1990, Smith et al. 1998, Russell et al. 2010). The large differences between species suggest a strong impact of native tree species on soil properties and gas fluxes in the clayrich, upland soils of the Amazon basin.

As we predicted, we found that tree species effects in monoculture were more pronounced than in the forest. Our results are consistent with Murphy et al. 2008, Brechet et al. 2009 and Russell et al. 2010 who also found that tree growth and soil $\mathrm{CO}_{2}$ fluxes on tree plantations were influenced by tree species. The species differences observed for standing biomass and $\mathrm{CO}_{2}$ flux were well within the range measured in other tropical plantations (Murphy et al. 2008, Brechet et al. 2009, Russell et al. 2010). Though we did not conduct a full carbon balance analysis at the plantation, our results indicate that different species can have large differences in the overall impact on climate change mitigation (Table 3). Fast growing species, such as $S$. chrysophyllum and $C$. multijuga, are associated with low $\mathrm{CO}_{2}$ and $\mathrm{N}_{2} \mathrm{O}$ fluxes. Conversely, $C$. guianensis, a species widely planted in monoculture for its medicinal oil, has relatively low carbon storage and high soil $\mathrm{CH}_{4}, \mathrm{CO}_{2}$, and $\mathrm{N}_{2} \mathrm{O}$ fluxes. The latter is the least favorable from a greenhouse gas perspective.
TABLE 6. Tree leaf carbon and nitrogen content and isotope composition ( $\pm S E$ ) on the plantation and in the Tapajos National Forest.

\begin{tabular}{lcccc}
\hline & $\delta^{13} \mathrm{C}$ & $\delta^{15} \mathrm{~N}$ & $\% \mathrm{C}$ & $\% \mathrm{~N}$ \\
\hline Plantation & & & & \\
Non-legume (18) & $-30.6 \pm 0.3$ & $3.6 \pm 0.3$ & $45.9 \pm 0.5$ & $2.0 \pm 0.1$ \\
Legume (10) & $-32.3 \pm 0.4$ & $3.9 \pm 0.2$ & $48.9 \pm 0.5$ & $2.2 \pm 0.2$ \\
Student's $t$ & 3.4 & 0.9 & 5.0 & 1.3 \\
Two-sided $P$ & 0.003 & 0.37 & $<0.001$ & 0.20 \\
Forest clay & & & & \\
Non-legume (44) & $-29.4 \pm 0.2$ & $7.0 \pm 0.4$ & $48.7 \pm 0.8$ & $1.9 \pm 0.1$ \\
Legume (36) & $-29.8 \pm 0.2$ & $7.2 \pm 0.2$ & $50.2 \pm 0.3$ & $2.2 \pm 0.1$ \\
Student's $t$ & 2.1 & 0.3 & 1.8 & 1.7 \\
Two-sided $P$ & 0.13 & 0.76 & 0.10 & 0.11 \\
\hline
\end{tabular}

*Forest data were extracted from Ehleringer et al. (2010).

The tree species data for the different greenhouse gases suggests that species selection for monoculture plantations is most impacted by $\mathrm{CO}_{2}$ exchange, followed by $\mathrm{N}_{2} \mathrm{O}$ and then $\mathrm{CH}_{4}$ (Table 3).

EFFECT OF LEGUME SPECIES.-As fast growing, early successional species that can provide their own nitrogen demand, many legumes are especially suitable to be planted in monoculture on poor soils, such as depleted former agricultural lands (Piotto 2008, Siddique et al. 2008, Palm et al. 2010). However, many studies suggest that legume species will strongly increase the $\mathrm{N}_{2} \mathrm{O}$ flux relative to other plantation species (Palm et al. 2002, 2010, Dick et al. 2006, Arai et al. 2008, Hergoualc'h et al. 2008), as invasive species in primary forests (Hall \& Asner 2007), and in secondary forests (Erickson et al. 2001). This increase has invariably been linked to the $\mathrm{N}$-fixing capability of legumes. In contrast, a recent review of $\mathrm{N}_{2} \mathrm{O}$ flux emissions in legume crops and plantations compared with fertilized crop lands suggests that $\mathrm{N}_{2} \mathrm{O}$ fluxes are not particularly high in crop and tree plantations (Jensen et al. 2012). 
In our study, the three legume species all had the highest biomass on the plantation, but without the expected high soil $\mathrm{N}_{2} \mathrm{O}$ fluxes (Table 3). The low $\mathrm{N}_{2} \mathrm{O}$ fluxes were especially surprising because, after inspection of excavated roots, we found all legumes on the plantation to be nodulated. As is common in tropical forests (Barron et al. 2011), the legume species in our study apparently were not investing resources in $\mathrm{N}$-fixation, because leaf $\delta^{15} \mathrm{~N}$ values of legumes were not different from non-legumes (Table 6). The species with leaf $\delta^{15} \mathrm{~N}$ values $(1.6 \%$ $M$. buberi and $2.0 \%$. maxima) are species normally not associated with N-fixation. Though Russell and Raich (2012) found the lowest leaf $\delta^{15} \mathrm{~N}$ values in a Vochisia species in a plantation in Costa Rica, suggesting that this genus can be associated with N-fixation on plantations. $M$. buberi leaves also had very low $\mathrm{N}$-content, which suggests that $\mathrm{N}$ supplied from epiphytic $\mathrm{N}$-fixers could supply them with the necessary $\mathrm{N}$ (Reed et al. 2008).

Several mechanisms could explain the particularly low $\mathrm{N}_{2} \mathrm{O}$ fluxes on the legume plots in monoculture: (1) low $\mathrm{N}_{2} \mathrm{O}$ fluxes were paired with low \%WFPS on the legume plots (Fig. 1), and (2) the high carbon demand of N-fixation and high tree growth rates leave little carbon for denitrification. Higher growth rates and stand densities could create a higher water demand per unit soil volume, through increased transpiration. Lower ${ }^{13} \mathrm{C}$ values of legume leaves on the plantation (indicative of higher stomatal conductance, Table 6) and the negative correlation between tree growth rate and soil WFPS support that increased transpiration might have caused a higher water demand of legumes. We deem the second mechanism-reduced carbon availability due to $\mathrm{N}$-fixation a less likely cause for reduced $\mathrm{N}_{2} \mathrm{O}$ fluxes on legume plots. Although $\mathrm{N}_{2}$ fixation is known to be a highly $\mathrm{C}$ and $\mathrm{P}$ intensive process (Davidson 2008), the lack of leaf $\delta^{15} \mathrm{~N}$ difference between legumes and non-legumes on the plantation suggest that rhizobial N-fixation was not a significant process.

Predictive Capability of MONOCUlture plantations for tree SPECIES EFFECTS IN FORESTS.-The different $\mathrm{N}_{2} \mathrm{O}$ flux rank order of tree species in the forest and on the plantation suggests that, except for the growth rate, little inference about species effects can be made from the plantation to the forest and vice versa. Similarly, in mixed species plantations little relationship between the species associated soil differences found in monoculture persisted in the more diverse ( $\max 6$ species) forest (Kelty 2006, Murphy et al. 2008). To our knowledge, the only studies that have investigated the same species in a plantation and neighboring forest were Hattenschwiler et al. (2008), comparing leaf chemistries, and Gei and Powers (2013), comparing soil properties under species in monoculture and a secondary forest. From these limited studies it appears that tree properties (leaf chemistry (Hattenschwiler et al. 2008) and stem growth rates, this study) appear to be conservative and species rank orders preserved in monoculture and diverse forests. In contrast, the ranked effect of tree species on soil properties (Gei \& Powers 2013, and this study) is highly different between monocultures and diverse forests.
The lack of predictability of forest soil gas fluxes and properties based on species identity on the plantation may be resolved by using quantitative tree properties, such as leaf chemistry and tree growth rate. Hattenschwiler et al. (2008) found the same rank order of leaf chemical properties (C, N, and P composition) of four tree species in a plantation and nearby forest in French Guiana. This suggests that tree species experiencing similar climate and soil conditions have a similar nutrient demand and chemical litter quality, thus should have predictable soil $\mathrm{N}_{2} \mathrm{O}$ fluxes (e.g., decomposition, nutrient release, etc.). The lack of predictability between the plantation and forest at our site in Brazil, and a poor correlation between leaf chemistry and soil $\mathrm{N}_{2} \mathrm{O}$ fluxes, suggest that trees influence soil $\mathrm{N}_{2} \mathrm{O}$ fluxes through mechanisms other than decomposition or nutrient acquisition. Labile carbon supply from roots to dentrifiers could increase soil $\mathrm{N}_{2} \mathrm{O}$ production. A recent study found that tree growth is positively correlated with fine root growth (Russell et al. 2010), which combined with the expectation that increased carbon transport to fine roots increases soil $\mathrm{N}_{2} \mathrm{O}$ fluxes (Baggs 2011). By contrast, we found a negative correlation between tree growth rate and soil $\mathrm{N}_{2} \mathrm{O}$ fluxes. This apparent contradiction could be the result of increased water use by fast growing trees, which lowers soil WFPS and thus counter the positive effect of increased belowground carbon on dentrification. Further research will be required to resolve the mechanism behind tree species influence on soil $\mathrm{N}_{2} \mathrm{O}$ fluxes.

\section{CONCLUSIONS}

Our study combining monoculture plantation plots and diverse forest sites on texturally similar soil confirmed that soil gas fluxes and properties are strongly dependent on the planted tree species in monoculture plantations and less so in the diverse forest. We found species effects only for soil $\mathrm{N}_{2} \mathrm{O}$ fluxes in both forest and plantation, and that tree species growth rate and soil WFPS were the best predictors for $\mathrm{N}_{2} \mathrm{O}$ fluxes both in monoculture and diverse forests. These results indicate that we cannot compare the species effects on the plantation with mean forest values (e.g., Smith et al. 1998). Unless we test species effects in plantations and forests, little knowledge will be gained about how species interactions change individual species effects. Although native species are the minority of species planted in plantations on abandoned farm-land (FAO 2010), the potential carbon sequestration benefit of native tree species should be taken into consideration when plantations are planned.

\section{ACKNOWLEDGMENTS}

The authors thank the LBA Santarem and EMBRAPA Belterra offices for logistic support and Francisco Alves Freitas Neto, Cleuton Pereira, Jackson da Silva, Marcello da Silva Feitoso, Felipe Saita, and Nilson de Souza Carvalho, for their invaluable help in the field and lab. We are grateful to Jennifer Powers and three anonymous reviewers for their insightful comments. The research was conducted with funding through a U.S. Forest Service grant to MK and a NSF-PIRE fellowship to $\mathrm{JvH}$. 


\section{SUPPORTING INFORMATION}

Additional Supporting Information may be found in the online version of this article:

APPENDIX S1. Site locations, species selected, and semi-variogram analysis,

FIGURE S1. Map of Brazil with site locations and detailed transect information for the $\mathrm{km} 67$ forest site in the Tapajos National Forest.

FIGURE S2. Semi-variogram plots of bulk density, water filled pore space, $\mathrm{CO}_{2}$, and $\mathrm{N}_{2} \mathrm{O}$ flux for both the forest and plantation.

FIGURE S3. As Figure S2, but only for less than 50 and $100 \mathrm{~m}$ for the forest and plantation sites respectively.

\section{LITERATURE CITED}

Akimoto, F., A. Matsunami, Y. Kamata, I. Kodama, K. Kitagawa, N. Arai, T. Higuchi, A. Itoh, and H. Haraguchi. 2005. Cross-correlation analysis of atmospheric trace concentrations of $\mathrm{N}_{2} \mathrm{O}, \mathrm{CH}_{4}$ and $\mathrm{CO}_{2}$ determined by continuous gas-chromatographic monitoring. Energy 30: 299-311.

Arai, S., S. Ishizuka, S. Ohta, S. Ansori, N. Tokuchi, N. Tanaka, and A. Hardjono. 2008. Potential $\mathrm{N}_{2} \mathrm{O}$ emissions from leguminous tree plantation soils in the humid tropics. Global Biogeochem. Cycles 22. doi:10.1029/2007GB002965.

BAGGS, E. M., 2011. Soil microbial sources of nitrous oxide: Recent advances in knowledge, emerging challenges and future direction. Curr Opin Env Sust 3: 321-327.

Barron, A. R., D. W. Purves, and L. O. Hedin, 2011. Facultative nitrogen fixation by canopy legumes in a lowland tropical forest. Oecologia 165: 511-520.

Binkley, D., and O. Menyailo. 2005. Gaining insights on th effects of tree species on soils. In D. Binkley, and O. Menyailo (Eds.). Tree species effects on soils: Implications for global change, pp. 1-16. Spinger, Dordrecht, The Netherlands.

Brechet, L., S. Ponton, J. Roy, V. Freycon, M. M. Couteaux, D. Bonal, And D. Epron. 2009. Do tree species characteristics influence soil respiration in tropical forests? A test based on 16 tree species planted in monospecific plots. Plant Soil 319: 235-246.

Breuer, L., H. Papen, and K. Butterbach-Bahl. 2000. N2O emission from tropical forest soils of Australia. J. Geophys. Res. Atmos. 105: 2635326367.

Cerri, C. E. P., M. C. Piccolo, B. J. Feigl, K. Paustian, C. C. Cerri, R. L. Victoria, ANd J. M. Melillo. 2006. Interrelationships among soil total $\mathrm{C}$ and $\mathrm{N}$, microbial biomass, trace gas fluxes, and internal $\mathrm{N}$-cycling in soils under pasture of the Amazon region. J. Sustainable Agric. 27: 45-69.

Chave, J., C. Andalo, S. Brown, M. A. Cairns, J. Q. Chambers, D. Eamus, H. Folster, F. Fromard, N. Higuchi, T. Kira, J. P. Lescure, B. W. Nelson, H. Ogawa, H. Puig, B. Riera, and T. Yamakura. 2005. Tree allometry and improved estimation of carbon stocks and balance in tropical forests. Oecologia 145: 87-99.

Davidson, E. A. 2008. Biogeochemistry: Fixing forests. Nat. Geosci. 1: 421422.

Davidson, E. A., C. J. R. de Carvalho, A. M. Figueira, F. Y. Ishida, J. P. H. B. Ometto, G. B. Nardoto, R. T. Saba, S. N. Hayashi, E. C. Leal, I. C. G. Vieira, and L. A. Martinelli. 2007. Recuperation of nitrogen cycling in Amazonian forests following agricultural abandonment. Nature 447: 995-U996.
Davidson, E. A., D. C. Nepstad, F. Y. Ishida, and P. M. Brando. 2008. Effects of an experimental drought and recovery on soil emissions of carbon dioxide, methane, nitrous oxide, and nitric oxide in a moist tropical forest. Global Change Biol. 14: 2582-2590.

DeFries, R., and C. Rosenzweig. 2010. Toward a whole-landscape approach for sustainable land use in the tropics. Proc. Natl Acad. Sci. USA 107: 19627-19632.

Dick, J., U. Skiba, R. Munro, and D. Deans. 2006. Effect of N-fixing and non $\mathrm{N}$-fixing trees and crops on $\mathrm{NO}$ and $\mathrm{N}_{2} \mathrm{O}$ emissions from Senegalese soils. J. Biogeogr. 33: 416-423.

Ehleringer, J., L. A. Martinelli, J. P. H. B. Ometto, T. F. Domingues, L. Flanagan, J. Berry, C. Cook, and G. B. Nardoto. 2010. LBA-ECO CD-02 carbon, nitrogen, oxygen stable isotopes in organic material, Brazil. Available at: http://daac.ornl.gov from Oak Ridge National Laboratory Distributed Active Archive Center, Oak Ridge, Tennessee, U.S.A. doi:10.3334/ORNLDAAC/983 (accessed 13 June 2011).

Erickson, H., M. Keller, and E. A. Davidson. 2001. Nitrogen oxide fluxes and nitrogen cycling during postagricultural succession and forest fertilization in the humid tropics. Ecosystems 4: 67-84.

FAO. 2010. Global forest resources assessment 2010. Main report. FAO Forestry paper, p. 340. FAO, Rome, Italy.

Gei, M. G., AND J. S. Powers. 2013. Do legumes and non-legumes tree species affect soil properties in unmanaged forests and plantations in Costa Rican dry forests? Soil Biol. Biochem. 57: 264-272.

Hall, S. J., ANd G. P. Asner. 2007. Biological invasion alters regional nitrogen-oxide emissions from tropical rainforests. Global Change Biol. 13: 2143-2160.

van Haren, J. L. M., R. C. de Oliveira, N. Restrepo-Coupe, L. Hutyra, P. B. de Camargo, M. Keller, and S. R. Saleska. 2010. Do plant species influence soil $\mathrm{CO}_{2}$ and $\mathrm{N}_{2} \mathrm{O}$ fluxes in a diverse tropical forest? J. Geophys. Res. Biogeosci. 115: G03010. doi:03010.01029/02009jg001231.

Hattenschwiler, S., B. Aeschlimann, M. M. Couteaux, J. Roy, and D. BONAL. 2008. High variation in foliage and leaf litter chemistry among 45 tree species of a neotropical rainforest community. New Phytol. 179: 165-175.

Hattenschwiler, S., A. V. Tiunov, And S. Scheu. 2005. Biodiversity and litter decomposition interrestrial ecosystems. Annu. Rev. Ecol. Evol. Syst. 36: 191-218.

Hergoualc'h, K., U. Skiba, J. M. Harmand, and C. Henault. 2008. Fluxes of greenhouse gases from Andosols under coffee in monoculture or shaded by Inga densiflora in Costa Rica. Biogeochemistry 89: 329345.

IPCC, 2007. Climate Change 2007: The physical science basis. Contribution of working group I to the fourth assessment report of the Intergovernmental Panel on Climate Change. Cambridge University Press, Cambridge, UK and New York.

Ishizuka, S., A. Iswandi, Y. Nakajima, S. Yonemura, S. Sudo, H. Tsuruta, AND D. Murdiyarso. 2005. The variation of greenhouse gas emissions from soils of various land-use/cover types in Jambi province, Indonesia. Nutr. Cycl. Agroecosyst. 71: 17-32.

Jacob, M., N. Weland, C. Platner, M. Schaefer, C. Leuschner, and F. M. Thomas. 2009. Nutrient release from decomposing leaf litter of temperate deciduous forest trees along a gradient of increasing tree species diversity. Soil Biol. Biochem. 41: 2122-2130.

Jensen, E. S., M. B. Peoples, R. M. Boddey, P. M. Gresshoff, H. HauggAard-Nielsen, B. J. R. Alves, And M. J. Morrison. 2012. Legumes for mitigation of climate change and the provision of feedstock for biofuels and biorefineries. A review. Agron. Sustain. Dev. 32: 329-364.

Keller, M., R. Varner, J. D. Dias, H. Silva, P. Crill, and R. C. de Oliveira. 2005. Soil-atmosphere exchange of nitrous oxide, nitric oxide, methane, and carbon dioxide in logged and undisturbed forest in the Tapajos National Forest, Brazil. Earth Interact. 9: 1-28.

KeLty, M. J. 2006. The role of species mixtures in plantation forestry. For. Ecol. Manage. 233: 195-204. 
LinN, D. M., AND J. W. Doran. 1984. Effect of water-filled pore-space on carbon-dioxide and nitrous-oxide production in tilled and nontilled soils. Soil Sci. Soc. Am. J. 48: 1267-1272.

Matson, P. A., P. M. Vitousek, G. P. Livingston, and N. A. Swanberg. 1990. Sources of variation in nitrous-oxide flux from Amazonian ecosystems. J. Geophys. Res. Atmos. 95: 16789-16798.

Montagnini, F., And P. K. R. Nair. 2004. Carbon sequestration: An underexploited environmental benefit of agroforestry systems. Agrofor. Syst. 61-2: 281-295.

Montagnini, F., and F. Sancho. 1990. Impacts of native trees on tropical soils - A study in the Atlantic lowlands of Costa-Rica. Ambio 19: 386-390.

Murphy, M., T. Balser, N. Buchmann, V. Hahn, and C. Potvin. 2008. Linking tree biodiversity to belowground process in a young tropical plantation: Impacts on soil $\mathrm{CO}_{2}$ flux. For. Ecol. Manage. 255: 2577-2588.

Nardoto, G. B., J. P. H. B. Ometto, J. R. Ehleringer, N. Higuchi, M. M. D. Bustamante, and L. A. Martineldi. 2008. Understanding the influences of spatial patterns on $\mathrm{N}$ availability within the Brazilian Amazon forest. Ecosystems 11: 1234-1246.

Palm, C. A., J. C. Alegre, L. Arevalo, P. K. Mutuo, A. R. Mosier, and R. CoE. 2002. Nitrous oxide and methane fluxes in six different land use systems in the Peruvian Amazon. Global Biogeochem. Cycles 16: GB1073. doi:10.1029/2001gb001855.

Palm, C. A., S. M. Smukler, C. C. Suldivan, P. K. Mutuo, G. I. Nyadzi, and M. G. WALSH. 2010. Identifying potential synergies and trade-offs for meeting food security and climate change objectives in sub-Saharan Africa. Proc. Natl Acad. Sci. USA 107: 19661-19666.

Parotta, J. A., J. K. Francis, and R. R. de Almeida. 1995. Trees of the Tapajos. In F. S. United States Department of Agriculture (Ed.). International Institute of Tropical Forestry, p. 371. Rio Pedras, Puerto Rico.

PiotTo, D.2008. A meta-analysis comparing tree growth in monocultures and mixed plantations. For. Ecol. Manage. 255: 781-786.

Powers, J. S., M. H. Kalicin, and M. E. Newman. 2004. Tree species do not influence local soil chemistry in a species-rich Costa Rica rain forest. J. Trop. Ecol. 20: 587-590.

Pyle, E. H., G. W. Santoni, H. E. M. Nascimento, L. R. Hutyra, S. Vieira, D. J. Curran, J. van Haren, S. R. Saleska, V. Y. Chow, P. B. CarmaGo, W. F. Laurance, and S. C. Wofsy. 2008. Dynamics of carbon, biomass, and structure in two Amazonian forests. J. Geophys. Res. Biogeosci. 113. doi:10.1029/2007JG000592.

Ravishankara, A. R., J. S. Daniel, and R. W. Portmann. 2009. Nitrous oxide $\left(\mathrm{N}_{2} \mathrm{O}\right)$ : The dominant ozone-depleting substance emitted in the $21 \mathrm{st}$ century. Science 326: 123-125.

Reed, S. C., C. C. Cleveland, and A. R. Townsend. 2008. Tree species control rates of free-living nitrogen fixation in a tropical rain forest. Ecology 89: 2924-2934.

Ribeiro, P. J., And P. J. Diggle. 2001. GeoR: A package for geostatistical analysis. R-NEWS 1: 15-18.
Rice, A. H., E. H. Pyle, S. R. Saleska, L. Hutyra, M. Palace, M. Keller, P. B. de Camargo, K. Portilho, D. F. Marques, and S. C. Wofsy. 2004. Carbon balance and vegetation dynamics in an old-growth Amazonian forest. Ecol. Appl. 14: S55-S71.

Russell, J. A.1942. Fordlandia and Belterra, rubber plantations on the Tapajos river, Brazil. Econ. Geogr. 18: 125-145.

Russelt, A. E., AND J. W. RaICH. 2012. Rapidly growing tropical trees mobilize remarkable amounts of nitrogen, in ways that differ surprisingly among species. Proc. Natl Acad. Sci. USA 109: 10398-10402.

Russell, A. E., J. W. Raich, R. B. Arrieta, O. Valverde-Barrantes, and E. Gonzalez. 2010. Impacts of individual tree species on carbon dynamics in a moist tropical forest environment. Ecol. Appl. 20: 1087-1100.

Siddique, I., V. L. Engel, J. A. Parrotta, D. Lamb, G. B. Nardoto, J. P. H. B. Ometto, L. A. Martinelli, and S. Schmidt. 2008. Dominance of legume trees alters nutrient relations in mixed species forest restoration plantings within seven years. Biogeochemistry 88: 89-101.

Da Silva, J. M. L., P. M. dos Santos, A. A. C. Lima, J. S. Martins, T. E. ;Rodrigues, M. A. Valente, R. S. Rego, and E. Q. Cardoso. 2000. Levantamento semidetalhado dos solos do campo experimental de Belterra, estado do Para. p. 30. Embrapa Amazonia Oriental, Belem, PA, Brazil. (in Portuguese)

Silver, W. L., R. Ostertag, And A. E. Lugo. 2000. The potential for carbon sequestration through reforestation of abandoned tropical agricultural and pasture lands. Restor. Ecol. 8: 394-407.

Silver, W. L., A. W. Thompson, A. Reich, J. J. Ewel, and M. K. Firestone. 2005. Nitrogen cycling in tropical plantation forests: Potential controls on nitrogen retention. Ecol. Appl. 15: 1604-1614.

Smith, C. K., H. L. Gholz, And F. D. Oliveira. 1998. Soil nitrogen dynamics and plant-induced soil changes under plantations and primary forest in lowland Amazonia, Brazil. Plant Soil 200: 193-204.

Valverde-Barrantes, O. J. 2007. Relationships among litterfall, fine-root growth, and soil respiration for five tropical tree species. Can. J. For. Res. 37: 1954-1965.

Werner, C., K. Butterbach-Bahl, E. HaAs, T. Hickler, and R. Kiese. 2007. A global inventory of $\mathrm{N}_{2} \mathrm{O}$ emissions from tropical rainforest soils using a detailed biogeochemical model. Global Biogeochem. Cycles 21: Gb3010. doi:10.1029/2006gb002909.

Wick, B., E. Veldkamp, W. Z. de Mello, M. Keller, and P. Crill. 2005. Nitrous oxide fluxes and nitrogen cycling along a pasture chronosequence in Central Amazonia, Brazil. Biogeosciences 2: 175-187.

Williams, M., Y. E. Shimabukuro, D. A. Herbert, S. P. Lacruz, C. Renno, AND E. B. Rastetter. 2002. Heterogeneity of soils and vegetation in an eastern Amazonian rain forest: Implications for scaling up biomass and production. Ecosystems 5: 692-704. 